\title{
Suitable Sugar Level in Brown Fish Meal Diet for Tiger Puffer
}

\author{
Kenji Takii, ${ }^{* 1}$ Masaharu Ukawa, ${ }_{2}$ Motoji Nakamura, ${ }^{* 1}$ and Hidemi Kumai*1 \\ *IFisheries Laboratory, Kinki University, Uragami, Nachikatsuura, Wakayama 649-51, Japan \\ *2Technical Research Center, Marubeni Shiryo Co., Ltd., Ono, Hyogo 675-13, Japan
}

(Received December 22, 1994)

Tiger puffer Takifugu rubripes, weighing about $10 \mathrm{~g}$, were reared for 28 days on brown fish meal diets containing $10,13,16,19$, and $22 \%$ white dextrin.

Except for a low survival ( $75 \%$ ) obtained in the fish reared on the lowest white dextrin diet, the fish reared on other diets and sandeel, as a reference, showed high survival (>95\%). Under a similar daily ration size, the best weight gain, feed efficiency, and protein efficiency ratio were commonly noted in the fish fed the $16 \%$ dextrin diet. No marked differences among the dietary treatments were found in the proximate compositions of whole body and the hepatopancreas. Apparent digestibilities of dietary carbohydrate and protein remained high in the fish given $13-16 \%$ and $10-19 \%$ dextrin diets, respectively, using the intestinal digesta dissected at $5 \mathrm{~h}$ after feeding.

These results indicate that a suitable dietary dextrin level for the puffer is estimated around $16 \%$ and dietary carbohydrate content about $20 \%$.

Key words: tiger puffer, growth performance, digestibility, protein sparing effect, dietary sugar

Physiologically, tiger puffer Takifugu rubripes do not have a stomach but an expansion sac, a portion between the esophagus and the intestine, differentiating from an intestinal organ at their early life stages. ${ }^{1)}$ Moreover, somatic growth and digestion were improved by feeding a preferable diet supplemented with scallop Patinopecten yessoensis extract. ${ }^{1)}$ Kanazawa et $a .^{2)}$ had already shown that dietary levels of casein, pollack liver oil, mineral mixture, and vitamin mixture for the puffer were estimated at 50, un$\operatorname{der} 6$, at 4 , and at $3 \%$, respectively. Otherwise, Kakuta et al. ${ }^{3)}$ also showed that suitable dietary levels of white fish meal, pollack liver oil and dextrin were about 50, 8 and $34 \%$, respectively. The estimation of a suitable dietary sugar level in brown fish meal diet is necessary to conduct and progress the development of practical diet and the culture technique for the puffer.

\section{Materials and Methods}

\section{Test Diet}

Test diets 1-5 were composed of graded white dextrin levels of $10,13,16,19$, and $22 \%$ at the expense of cellulose, as appeared in Table 1 . All diets were commonly composed of $49 \%$ brown fish meal, $10 \%$ corn gluten meal, $5 \%$ pollack liver oil, $3 \%$ vitamin mixture, ${ }^{4)} 8 \%$ mineral mixture, ${ }^{4)}$ and $3 \%$ carboxymethylcellulose. Moreover, feeding stimulants, ${ }^{5)}$ mixture of L-aspartic acid, L-serine, glycine, L-alanine, and betaine, were supplemented to test diets for activating feeding of the puffer.

Test diets, a moist type pellet, were prepared using a laboratory pelleting machine after thoroughly mixing 100 parts of both the dry ingredients and pollack liver oil with 30 parts of cold tap water. Pellets, $1.9 \mathrm{~mm}$ in diameter and 2-3 $\mathrm{mm}$ in length, were stored at $-20^{\circ} \mathrm{C}$ until use.

Proximate compositions of test diets are shown in Table
Table 1. Formula and proximate composition of test diets $(\%)$

\begin{tabular}{|c|c|c|c|c|c|c|}
\hline \multirow{2}{*}{ Ingredient } & \multicolumn{5}{|c|}{ Diet } & \multirow{2}{*}{$\begin{array}{l}\text { Sand } \\
\text { eel }\end{array}$} \\
\hline & 1 & 2 & 3 & 4 & 5 & \\
\hline Brown fish meal & 49 & 49 & 49 & 49 & 49 & - \\
\hline Wheat gluten & 10 & 10 & 10 & 10 & 10 & - \\
\hline Pollack liver oil & 5 & 5 & 5 & 5 & 5 & - \\
\hline White dextrin & 10 & 13 & 16 & 19 & 22 & - \\
\hline Cellulose & 12 & 9 & 6 & 3 & - & - \\
\hline Vitamin mixture ${ }^{* 1}$ & 3 & 3 & 3 & 3 & 3 & - \\
\hline Mineral mixture ${ }^{*} 1$ & 8 & 8 & 8 & 8 & 8 & - \\
\hline CM-cellulose & 3 & 3 & 3 & 3 & 3 & 一 \\
\hline $\mathrm{FS}(\mathrm{g})^{*_{2}}$ & 1.183 & 1.183 & 1.183 & 1.183 & 1.183 & \\
\hline \multicolumn{7}{|c|}{ Proximate composition } \\
\hline Crude protein & 46.9 & 46.0 & 43.3 & 45.6 & 47.2 & 71.3 \\
\hline Crude fat & 8.7 & 9.0 & 8.9 & 9.4 & 9.1 & 14.4 \\
\hline Crude ash & 11.6 & 12.0 & 11.9 & 12.1 & 12.0 & 14.4 \\
\hline Crude sugar & 14.0 & 17.7 & 20.5 & 23.6 & 25.1 & - \\
\hline $\begin{array}{l}\text { Gross energy }{ }^{* 3} \\
\text { (kcal/ } 100 \mathrm{~g} \text { diet) }\end{array}$ & 405 & 418 & 413 & 443 & 456 & 539 \\
\hline
\end{tabular}

\footnotetext{
*1 Halver mixture. ${ }^{4}$

*2 Feeding stimulants (mg): L-aspartic acid; 21, L-serine; 24 , glycine; 329 , $\mathrm{L}$-alanine; 130 , and betaine; 679 .

${ }^{*}$ Gross energy (kcal/g): protein; 5.65 , fat; 9.45, and sugar; 4.10 .
}

1. Dietary crude sugar were $14.0,17.7,20.5,23.6$, and $25.1 \%$ in diets $1-5$, in that order. No marked differences were found in dietary crude protein, crude fat, and crude ash contents among test diets. Cutted sandeel Ammodytes personatus, as a reference, was given to compare growth performance with that of test diet groups.

The gross energy for dietary protein, fat, and sugar were based on values $5.65,9.45$, and $4.10 \mathrm{kcal} / \mathrm{g}$, respectively. ${ }^{6}$ 


\section{Fish and Feeding Trial}

The tiger puffer, having a mean body weight about $10 \mathrm{~g}$, which were reared in Fisheries Laboratory, Kinki University after artificial fertilization, were used for the present study. After domesticating the fish to rearing conditions on an artificial diet (Marubeni Shiryo Co., Ltd.) for 7 days, 12 groups of 20 fish each were accommodated into $300 \mathrm{l}$ indoor rectangular tanks $(60 \times 100 \times 50 \mathrm{~cm}$ deep $)$ under a running water system at $4 l$ filtered sea water per min. Water temperature during the feeding trial was $24.5 \pm$ $1.2^{\circ} \mathrm{C}$ (Mean $\pm \mathrm{SD} ; \mathrm{n}=28$ ). The puffer were fed on test diets 3 times a day, 6 days a week for 28 days. A daily ration size was adjusted about $2.7 \%$ of body weight through the feeding trial. A $12 \mathrm{~h}$ light:dark cycle was carryed under fluorescent tubes. The feeding trial was conducted under duplicated conditions.

On the initial and final day of feeding trial, the fish were weighed and then several fish were collected and decapitated to assay the proximate composition of whole body and the hepatopancreas. Growth performance of the dietary groups was estimated by the following expressions:

feed efficiency $=$ weight gain (wet) $/$ feed intake (dry)

$$
\text { /100; }
$$

protein efficiency ratio $=$ weight gain (wet)

$$
\text { /protein intake; }
$$

energy efficiency $=$ weight gain (wet)

$$
\text { /energy intake (kcal)/100; }
$$

and

$$
\text { apparent nutrient retention }=\text { body nutrient deposited }
$$

$$
\text { /nutrient intake/ } 100 \text {. }
$$

For measuring apparent protein and sugar digestibilities, the fish fasted for 2 days and were fed on the test diets with $0.5 \% \mathrm{Cr}_{2} \mathrm{O}_{3}$ after the end of feeding trial. We dissected the abdominal cavity and took out the intestines from 5 or 6 individuals in each group at $5 \mathrm{~h}$ after feeding, and then squeezed and pooled the intestinal digesta. The digesta was dried in an oven at $70^{\circ} \mathrm{C}$ for a day and stored in a desiccater at room temperature until assay.

\section{Assays}

The proximate compositions of the diets, whole body and the hepatopancreas were assayed by AOAC method.? Glycogen contents of the hepatopancreas and acid-digesti- ble carbohydrate (crude sugar) contents of the diets were respectively measured by the anthron method ${ }^{8)}$ and phenol-sulforic acid method. ${ }^{9}$ The digestibilities of dietary protein and sugar were assayed by the indirect method cited by Furukawa and Tsukahara. ${ }^{10)}$

\section{Statistical Analysis}

The data was analyzed by one-way ANOVA to detect an experimental treatment effect $(p<0.05)$, if this was sig. nificant, differences between dietary treatments were identified by Duncan's multiple range test $(p<0.05) .{ }^{11}$ The standard deviations obtained from duplicate lots were divided by 0.798 for estimating population. ${ }^{12)}$

\section{Results}

\section{Growth Performance}

Survival and growth performance of the tiger puffer which were fed the test diets are shown in Table 2. No infectious diseases were superficially noted on the fish throughout the feeding trial. Mortality was mainly attributed to serious injuries, loss of caudal fin and peduncle, by biting each other. Despite the hypersensitive characteristic of the puffer, relatively good growth was obtained in all dietary groups.

High survivals of $95.0-97.5 \%$ were maintained in the dietary groups, except $77.5 \%$ in the group fed the diet 1. Weight gain, feed efficiency, protein efficiency ratio, and energy efficiency improved significantly by increasing the dietary crude sugar up to $20.5 \%$ in diet 3 group, but fell above the content. The highest apparent protein retention was noted in the group fed the diet 4 containing $23.6 \%$ crude sugar, followed by the diet $3,5,2$, and 1 groups. Significant differences of the feed efficiency were not found among the reference feed group and diet 2-4 groups, but the weight gain, protein efficiency ratio, and energy efficiency of the latter groups were higher than the former group.

\section{Proximate Composition}

Tables 3 and 4 show the proximate composition of whole body and the hepatopancreas, respectively.

On the final day of the feeding trial, the crude protein content of whole body rose slightly by increasing the dietary crude sugar, and crude fat content in the diet 3 group

\begin{tabular}{|c|c|c|c|c|c|c|c|c|c|c|}
\hline \multirow{2}{*}{$\begin{array}{l}\text { Diet } \\
\text { group }\end{array}$} & \multirow{2}{*}{$\begin{array}{l}\text { Dietary } \\
\text { sugar } \\
(\%)\end{array}$} & \multicolumn{2}{|c|}{ Mean body weight $(\mathrm{g})$} & \multirow{2}{*}{$\begin{array}{l}\text { Daily feeding } \\
\text { rate } \\
(\%)\end{array}$} & \multirow{2}{*}{$\begin{array}{c}\text { Survival } \\
(\%)\end{array}$} & \multirow{2}{*}{$\begin{array}{l}\text { Growth } \\
\text { rate } \\
(\%)\end{array}$} & \multirow{2}{*}{$\begin{array}{c}\text { Feed } \\
\text { efficiency } \\
(\%)\end{array}$} & \multirow{2}{*}{$\begin{array}{l}\text { Protein } \\
\text { efficiency } \\
\text { ratio }\end{array}$} & \multirow{2}{*}{$\begin{array}{c}\text { Energy } \\
\text { efficiency } \\
(\%)\end{array}$} & \multirow{2}{*}{$\begin{array}{l}\text { Apparent protein } \\
\text { retention } \\
(\%)\end{array}$} \\
\hline & & Initial & Final & & & & & & & \\
\hline 1 & 14.0 & 10.3 & 25.7 & 2.60 & $77.5^{\mathrm{b} * 2}$ & $133.2^{b}$ & $102.0^{b}$ & $2.18^{b}$ & $25.2^{c}$ & $24.2^{\mathrm{bc}}$ \\
\hline 2 & 17.7 & 9.94 & 26.1 & 2.76 & $95.0^{\mathrm{a}}$ & $157.1^{\mathrm{ab}}$ & $112.7^{\mathrm{a}}$ & $2.51^{\mathrm{a}}$ & $27.0^{\mathrm{ab}}$ & $33.6^{\mathrm{ab}}$ \\
\hline 3 & 20.5 & 10.4 & 27.3 & 2.77 & $97.5^{a}$ & $163.3^{a}$ & $115.0^{\mathrm{a}}$ & $2.65^{\mathrm{a}}$ & $27.9^{\mathrm{a}}$ & $35.2^{\mathrm{a}}$ \\
\hline 4 & 23.6 & 10.0 & 25.8 & 2.68 & $95.0^{\mathrm{a}}$ & $155.5^{\mathrm{ab}}$ & $114.9^{\mathrm{a}}$ & $2.52^{\mathrm{a}}$ & $26.0^{b c}$ & $37.5^{\mathrm{a}}$ \\
\hline 5 & 25.1 & 10.3 & 25.8 & 2.80 & $95.0^{\mathrm{a}}$ & $144.4^{a b}$ & $107.5^{\mathrm{ab}}$ & $2.28^{\mathrm{b}}$ & $23.6^{d}$ & $33.2^{\mathrm{ab}}$ \\
\hline Sandeel & - & 10.9 & 25.9 & 2.53 & $95.0^{\mathrm{a}}$ & $134.2^{b}$ & $114.5^{\mathrm{a}}$ & $1.61^{\mathrm{c}}$ & $21.3^{e}$ & $19.7^{\mathrm{c}}$ \\
\hline $\mathrm{SE}^{*_{1}}$ & & & & & 3.13 & 6.91 & 2.62 & 0.06 & 0.33 & 2.79 \\
\hline
\end{tabular}
was only higher than those in other groups. There were no meaningful differences in moisture and crude ash of the whole body among the dietary treatments.

Table 2. Growth performance of the puffer fed test diets for 28 days

*1 Standard error of mean.

$*_{2}$ Values in the same column with different superscripts are significantly different $(p<0.05)$. 
Table 3. Proximate composition (\%) of whole body of the puffer fed test diets for 28 days

\begin{tabular}{lcccc}
\hline $\begin{array}{l}\text { Diet } \\
\text { group }\end{array}$ & Moisture & $\begin{array}{c}\text { Crude } \\
\text { protein }\end{array}$ & $\begin{array}{c}\text { Crude } \\
\text { fat }\end{array}$ & $\begin{array}{c}\text { Crude } \\
\text { ash }\end{array}$ \\
\hline Initial & 77.6 & 15.7 & 3.1 & 2.3 \\
Final & & & & \\
1 & 78.6 & 13.3 & 3.5 & 2.5 \\
2 & 77.6 & 14.5 & 3.5 & 2.3 \\
3 & 79.6 & 14.2 & 3.7 & 2.2 \\
4 & 78.0 & 15.2 & 3.4 & 2.4 \\
5 & 78.2 & 15.1 & 3.2 & 2.6 \\
Sandeel & 79.5 & 13.7 & 3.0 & 2.7 \\
\hline
\end{tabular}

Table 4. Hepatosomatic index and proximate composition (\%) of the puffer fed test diets for 28 days

\begin{tabular}{lcccccc}
\hline $\begin{array}{l}\text { Diet } \\
\text { group }\end{array}$ & $\begin{array}{c}\text { Hepatosomatic } \\
\text { index }\end{array}$ & Moisture & $\begin{array}{c}\text { Crude } \\
\text { protein }\end{array}$ & $\begin{array}{c}\text { Crude } \\
\text { fat }\end{array}$ & $\begin{array}{c}\text { Crude } \\
\text { ash }\end{array}$ & Glycogen \\
\hline Initial & $9.56 \pm 0.77^{*_{1}}$ & 38.1 & 7.9 & 49.7 & 0.60 & - \\
Final & & & & & & \\
1 & $8.06 \pm 0.86^{*_{2}}$ & 36.4 & 6.9 & 52.0 & 0.81 & 5.4 \\
2 & $8.16 \pm 0.75^{\mathrm{a}}$ & 36.2 & 6.8 & 50.4 & 0.61 & 5.2 \\
3 & $8.46 \pm 1.34^{\mathrm{a}}$ & 35.7 & 6.7 & 51.7 & 0.60 & 8.5 \\
4 & $8.02 \pm 0.39^{\mathrm{a}}$ & 34.3 & 6.3 & 54.9 & 0.70 & 6.0 \\
5 & $8.07 \pm 0.53^{\mathrm{a}}$ & 36.6 & 6.5 & 52.1 & 0.60 & 8.8 \\
Sandeel & $7.13 \pm 0.65^{\mathrm{b}}$ & 36.4 & 7.0 & 50.5 & 0.74 & 4.0 \\
\hline
\end{tabular}

"Mean $\pm S D(n=10)$.

*2 Values in the same column with different superscripts are significantly different $(p<0.05)$.

Table 5. Apparent sugar and protein digestibilities using intestinal digesta dissected at $5 \mathrm{~h}$ after feeding

\begin{tabular}{lccccc}
\hline \hline \multirow{2}{*}{ Digestability } & \multicolumn{5}{c}{ Diet group } \\
\cline { 2 - 6 } & 1 & 2 & 3 & 4 & 5 \\
\hline Sugar & 38.2 & 43.0 & 45.7 & 39.2 & 38.3 \\
Protein & 46.8 & 50.1 & 47.1 & 45.2 & 26.7 \\
\hline
\end{tabular}

No significant differences were detected in the hepatosomatic indices among test diet groups, but that of the group fed sandeel was significantly lower than those of test diet groups on the final day of the feeding trial. Marked differences in moisture, crude protein, crude fat, and crude ash contents of the hepatopancreas were also not found among the dietary groups on the final day. The highest glycogen was accumulated in the diet 5 group, followed by diet $3,4,1$, and 2 groups. The lowest glycogen content was detected in the reference group.

\section{Apparent Digestibility of Sugar and Protein}

Digestibilities assayed using intestinal digesta are shown in Table 5 . Sugar digestibilities of diets 2 and 3 were about $44 \%$, which were slightly higher than those of diets 1,4 , and 5 by about $38 \%$. Meanwhile, protein digestibilities of diets $1-4$, up to $23.6 \%$ dietary crude sugar, were commonly about $47 \%$, being higher than that of diet 5 , having the highest white dextrin level.

\section{Discussion}

We adopted a 4-week feeding trial in the present study. The short feeding period was obligated to the hypersensitive character of tiger puffer, such as serious injuries caused by biting each other, as cited above.

The digestible energy for dietary nutrients had not been estimated in the puffer. Then, we used gross energy values for dietary protein, fat, and sugar as $5.65,9.45$, and 4.10 $\mathrm{kcal} / \mathrm{g},{ }^{6)}$ respectively. There are problems to use such convenient values for determining dietary energy content, but these values were necessary as an indicator for formulating test diet compositions.

From the present study, we could indicate that the suitable dextrin level of the diet for the puffer is $16 \%$, dietary crude sugar being about $20 \%$. The difference in the suitable dietary dextrin level between the present study and the previous report ${ }^{3)}$ might result from the differences of experimental conditions, such as body weights of the puffer used, or other dietary ingredients, and rearing conditions. The formula of diet 3 in the present study is more profitable for the puffer-culture because brown fish meal has been most vigorously and currently used as a dietary protein source for fish-cultures in Japan.

The low sugar utility of fish was ordinarily estimated as compared with terrestrial mammals. ${ }^{13,14)}$ Shimeno, ${ }^{15)}$ Nagai and Ikeda, ${ }^{16,17)}$ and Furuichi ${ }^{18)}$ studied on the carbohydrate metabolism of yellowtail Seriola quiqueradiata, carp Cyprinus carpio, and red sea bream Pagrus major, respectively. These reports suggested that low amylase and hepatic glycolytic enzyme activities, shortage of insulin synthesis and secretion, and high activities of hepatic enzymes relating gluconeogenesis resulted in the low sugar utilization of fishes. Amino acids and fatty acids were preferably used in fishes for energy source. ${ }^{19)}$ The suitable dietary sugar level for yellowtail, carp, and red sea bream was estimated about 10,35 , and $15 \%$, respectively. ${ }^{15,18)}$ Ikeda $^{19)}$ suggested that the differences of sugar utility among fishes were related to their feeding habits and migration. Juveniles, young, and adult tiger puffers that preferentially ate crustaceans and juvenile fin fishes are carnivorous fish. ${ }^{20)}$ Judging from the relatively high sugar utility, the puffer is suspected to be classified with the omnivorous fish rather than the absolute carnivorous fish such as the yellowtail and the red sea bream. The ecological character of the puffer, feeding selection, migration, mating, and others are now being estimated. Much understanding of their character will surely make progress in improving the culture technique of the tiger puffer.

The puffers fed diet 3 , having $20 \%$ dietary crude sugar, had the best protein efficiency ratio and relatively high apparent protein retention in the diet groups. This indicates the protein sparing effect by dietary sugar in the puffer. Based on the protein efficiency ratio of the dietary groups, the quantitative requirements of protein for $100 \mathrm{~g}$ weight gain were calculated as $45.9,40.9,37.7,39.7$, and $43.9 \mathrm{~g}$ in the diet $1,2,3,4$, and 5 groups, respectively. In comparison with the diet 1 group, therefore, the sparing effect by dietary sugar for dietary protein was estimated to be 17.9 and $13.5 \%$ in the diet 3 and 4 groups, respectively. It has already been shown in terrestrial animals that glucose 
depresses many degradative reactions of protein in tissues. ${ }^{21)}$ This mechanism might support the protein sparing effect of dietary sugar in the puffer. Shimeno ${ }^{22)}$ suggested that sugar is not always necessary to maintain fish growth and health, but should be consciously used to spare dietary proteins as well as to lower feed costs economically. Otherwise, Takeda ${ }^{23)}$ and Cowey et al. ${ }^{24)}$ showed the protein sparing effect was more preferable to supplement the proper ratio of both fat and sugar than only fat in yellowtail and plaice Pleuronectes platessa. We intend to clarify the optimum fat level in BFM diet and the additional effect of fat to sugar supplement on the protein sparing in the puffer.

Although low digestibilities were ordinarily detected by using intestinal digesta squeezed at $5 \mathrm{~h}$ after feeding, relatively high sugar and protein digestibilities were detected in the diet 2 and 3 groups and the diet 1-4 groups, respectively. These supported the good growth performance of the diet 3 group. The fish fed diet 5 , having $25 \%$ dietary crude sugar, showed low sugar and protein digestibilities which were comparable to half of those in the diet 3 group. Kitamikado et al. ${ }^{25)}$ and Shimeno ${ }^{15)}$ also reported that protein and sugar digestibilities fell with relatively large increases of dietary sugar content in yellowtail. It is of great interest to infer what control the synthesis, secretion, and activation of digestive enzymes in fish; it is possible that complex mechanisms, such as nervous system via chemical input, ${ }^{1,26)}$ gastrointestinal hormones, the balance of dietary nutrients, correlation between nutrient assimilation and endocrine hormone secretion, are involved in this process. The puffer does not have a stomach. Many differences in digestive process of dietary nutrients are expected between the puffer and fish that have stomachs, such as rainbow trout, yellowtail, and red sea bream.

In conclusion, around $20 \%$ dietary crude sugar was suitable for the tiger puffer, when $49 \%$ brown fish meal, $10 \%$ wheat gluten, $16 \%$ white dextrin, and $5 \%$ pollack liver oil were used as protein, sugar, and lipid sources, respectively. Relatively high content of dietary sugar profits to prepare an expanding and paste type diet and to lower feed cost for tiger puffer-culture. The paste type diet may be more reasonable for the tiger puffer, considering the shape of their teeth and feeding behavior.

Acknowledgments The authors thank the staff of the Fisheries Laboratory, Kinki University, Uragami and Kinki University Fish Nursery Center for their technical support. Thanks are also due to T. Kumashiro, who graduated from the Department of Fisheries, Kinki University, for his technical assistance.

\section{References}

1) H. Kumai, I. Kimura, M. Nakamura, K. Takii, and H. Ishida: Studies on digestive system and assimilation of a flavored diet in ocellate puffer. Nippon Suisan Gakkaishi, 55, 1035-1043 (1989).

2) A. Kanazawa, S. Teshima, M. Sakamoto, and A. Shinomiya: Nutritional requirements of the puffer fish: purified test diet and the optimum protein level. Nippon Suisan Gakkaishi, 46, 1357-1361 (1980).

3) I. Kakuta, M. Okabe, K. Nanba, H. Nakagawa, H. Kumai, and M. Nakamura: Studies on nutritional requirement of fugu-III. effect of dietary dextrin, feed oil and vitamins. Suisanzoshoku, 36, 183-191 (1988) (in Japanese).
4) J. E. Halver: Nutrition of salmonid fish-III. water-soluble vitamin requirements of chinook salmon. J. Nutr., 62, 225-243 (1957).

5) O. Takaoka, K. Takii, M. Nakamura, H. Kumai, and M. Takeda: Identification of feeding stimulants for tiger puffer. Fisheries Sci., 61, 833-836 (1995).

6) N. Hosoya and Y. Mori: Nutritional physiology, Asakura Shoten, Tokyo, 1980, pp. 206-220 (in Japanese).

7) AOAC: Official methods of analysis of the Association of Official Analytical Chemists, 14th edition, Arlington, VA, 1984, pp. 11141.

8) N. V. Carroll, R. W. Longley, and J. H. Roe: The determination of glycogen in liver and muscle by use of anthrone reagent. $J$. Biol. Chem., 220, 583-593 (1956).

9) J. E. Hodge and B. T. Hofreiter: Determination of reducing sugars and carbohydrates, in "Methods in Carbohydrate Chemistry" (ed. by R. L. Whistler and M. L. Wolfrom), Vol. 1, Academic Press, New York, 1962, pp. 388-389.

10) H. Furukawa and H. Tsukahara: On the acid digestion method for the determination of chronic oxide as an index substance in the study of digestibility of fish feeds. Nippon Suisan Gakkaishi, 32, 502-506 (1966) (in Japanese).

11) H. L. Harter: Critical values for Duncan's new multiple range tests. Biometrics, 16, 671-685 (1960).

12) S. Ishii: Introduction of statistic, Baifukan, Tokyo, 1975, pp. 36-64 (in Japanese).

13) B. Hepher: Metabolism of carbohydrate, in "Nutrition of Pond Fish", Cambridge University Press, Cambridge, 1988, pp. 64-88.

14) C. B. Cowey and J. R. Sargent: Nutrition, in "Fish Physiology" (ed. by W. S. Hoar, D. J. Randall, and J. R. Brett", Vol. 8, Academic Press, New York, 1979, pp. 1-70.

15) S. Shimeno: Studies on carbohydrate metabolism in fishes. Rep. Fish. Lab., Kochi Univ., No. 2, 1-107 (1974) (in Japanese).

16) M. Nagai and S. Ikeda: Carbohydrate metabolism in fish-N. effect of starvation and dietary composition on the blood glucose level and the hepatopancreatic glycogen and lipid contents in carp. Nippon Suisan Gakkaishi, 37, 404-409 (1971).

17) M. Nagai and S. Ikeda: Carbohydrate metabolism in fish-V. effect of dietary composition on metabolism of glucose- $\mathrm{U}^{-14} \mathrm{C}$ in carp. Nippon Suisan Gakkaishi, 37, 410-414 (1971).

18) M. Furuichi: Studies on the utilization of carbohydrate by fishes Rep. Fish. Res. Lab., Kyushu Univ., No. 6, 1-59 (1983).

19) S. Ikeda: Carbohydrate metabolism, in "Trace Elements in Aquatic Organisms-Their Biochemistry and Food Chemistry" (ed. by S. Ikeda), Koseisha Koseikaku, Tokyo, 1981, pp. 58-65 (in Japanese).

20) A. Ochiai and M. Tanaka: Tiger puffer, in "Ichthyology", Vol. 2, Koseisha Koseikaku, Tokyo, 1986, pp. 1024-1026 (in Japanese).

21) T. Noguchi and $H$. Naito: Mechanism and regulation of intracellular protein degradation, in "Proteins and Amino Acids"' (ed. by A. Yoshida, H. Naito, Y. Niiyama, and T. Suzuki), Japan Sci. Soc. Press, Tokyo/Springer-Verlag, Berlin, 1990, pp. 21-34.

22) S. Shimeno: Carbohydrate, in "Nutrition and Feed of Fishes" (ed. by C. Ogino), Koseisha Koseikaku, Tokyo, 1980, pp. 140-149 (in Japanese).

23) M. Takeda: Protein sparing effect, in "Fish Culture and Dietary Fat" (ed. by Japan. Soc. Sci. Fish.), Koseisha Koseikaku, Tokyo, 1978, pp. 78-92 (in Japanese).

24) C. B. Cowey, J. W. Adron, and D. A. Bron: Studies on the nutrition of marine flatfish. the metabolism of glucose by plaice (Pleuronectes platessa) and the effect of dietary energy source on protein utilization in plaice. Br. J. Nutr., 33, 219-231 (1965).

25) M. Kitamikado, T. Morishita, and S. Tachino: Digestibility of dietary protein in rainbow trout-II. effect of starch and oil contents in diets, and size of fish. Nippon Suisan Gakkaishi, 30, 50-54 (1964) (in Japanese).

26) K. Takii, S. Shimeno, M. Akutsu, and M. Takeda: Dietary supplement of feeding stimulants on performance and digestive function of yellowtail, Seriola quinqueradiata. Bull. Fish. Lab. Kinki Univ., No. $4,127-137$ (1994). 